\title{
Komposisi Tari Bunga di Atas Karang
}

\author{
DARMAWAN DADIJONO* \\ Jurusan Tari, Fakultas Seni Pertunjukan, Institut Seni Indonesia Yogyakarta
}

\begin{abstract}
The Composition of "Flower on Coral" Dance is about a transformational phenomenon realized into a dance called "Flower on Coral." An art performance cannot be separated from its stage since it is an important and integrated part of the art performance itself. Space of the performance becomes the main convention to build artistic communication between the star and the audience. Choices of the staging form are not just for building physical distance but also building spirit. The ritual aspect of the dance is dealt by the presence of an art performance. Humans' art which becomes inseparable part of the nature is expected to raise new religious space for the humans to believe in God. 'Walk by the Cross' is a Catholic tradition used to improve humans' spiritual life. Many Catholics do this tradition just as Jesus Christ did. So, there are many places built for religious visits and to experience the passion of Christ harder before He died.
\end{abstract}

Key words: dance, compotition, coral

\section{Pendahuluan}

Seni adalah media yang universal sehingga mampu berbicara berbagai hal, misalnya gaya hidup manusia, politik dan sosial, bahkan suatu keyakinan maupun kepercayaan. Seni adalah ekspresi kreatif seniman sebagai tanggapan renungannya atas hidup masyarakat mulai dari yang bersifat menghibur sampai yang mencerahkan; bisa komentar atas situasi, rangkuman, potret keadaan, karikatur, simbolisme, hingga ekspresi tragedi yang tragis (Mudji Sutrisno, 2003: 343).

Seni sebagai hasil ekspresi seniman terwujud dengan adanya cipta, rasa dan karsa. Hasilnya pun bermacam-macam sesuai dengan kedalaman dan pengalaman dalam menjalankan prosesnya. Proses berkarya seni sangat menentukan hasil yang dibuat sehingga sebuah proses harus dilalui dan dilakukan secara serius. Karya seni akan berhasil jika memberikan kesan dan pesan kepada penikmatnya, baik secara lahir maupun batin. Bagi seniman belum menjadi sebuah kepuasan karena segala kekurangan dan kelebihan karya seni, hanya seniman penciptanya yang tahu dan mengerti. Karya seni pun pada tahap keberhasilannya tidak- lah luput dari faktor ruang dan waktu, kapan dan di mana karya seni itu ditampilkan.

Seniman mempunyai kebebasan dalam berekspresi. Kreativitas menjadi bekal yang utama dalam membuat karya seni yang berkembang dan inovatif. Ide-ide yang timbul dari seniman belum menjadi sebuah karya seni manakala ide tersebut belum diwujudkan.

Inovasi selalu berawal dari individu-individu, karena pada dasarnya inovasi adalah ide, dan ide hanya ada dalam pikiran individu yang tidak lepas dari persentuhannya dengan disiplin lain, seperti teater, arsitektur, seni rupa, music dan sebagainya (bandingkan dengan Supadma, 2004: 59). Sebagai ide, inovasi baru akan dapat diketahui jika telah diwujudkan, dinyatakan, lewat gerak, benda atau pun sesuatu yang empiris, seperti tulisan. Seseorang yang mempunyai ide-ide baru tidak akan pernah diketahui oleh orang lain sebelum dia menyampaikannya kepada orang lain, melalui media yang bermacam-macam.

Sebuah pementasan karya seni tidak terlepas dari tempat pementasan itu sendiri berlangsung. Tempat pementasan dan pergelaran merupakan

\footnotetext{
*Alamat korespondesnsi: Jln. Parangtritis Km 6.5 Sewon, Yogyakarta, Tlp.0274-375380, e-mail: darmawantari@gmail.com
} 
bagian penting dan terintegrasi dengan sajian karya seni yang ditampilkan. Ruang dan tempat pergelaran menjadi konvensi dasar untuk membangun komunikasi seni antara pemain dengan khalayak penonton (audience). Pilihan atas bentuk pemanggungan bukan sekedar untuk menciptakan jarak fisik, akan tetapi merupakan penentuan tingkat keterlibatan audience terhadap pementasan, baik keterlibatan fisik maupun batin

Goa Maria Tritis merupakan salah satu tempat yang ada di Yogyakarta sebagai tempat ziarah umat Katolik. Kondisi pegunungan yang kering menjadikan tempat ini mempunyai karakter tersendiri. Rute jalan salib yang ada di Goa Maria Tritis mempunyai karakter jalan yang berliku. Jalan naik dengan ketinggian yang berbeda, jalan yang menurun terjal, di sisi jalan lereng dan jurang menambah kekuatan rute jalan salib yang sangat berat. Jalan Salib merupakan sebuah tradisi yang ada pada ajaran agama Katolik, yang bermanfaat untuk memupuk hidup rohani. Dalam perlakuannya tidak sedikit umat Katolik melakukan tradisi ini bukan hanya berdoa di tempat, namun tidak sedikit orang melakukan tradisi jalan salib. Jalan-jalan dihiasi bukit-bukit dan semak belukar, serta hutan jati. Di penghujung rute jalan salib dijumpai sebuah goa yang masih alami. Stalagtit dan stalagmit menghiasi bagian dalam goa. Suasana sejuk dan tenang dalam goa ini menjadikan tempat ini cocok untuk kontemplasi bahkan Ekaristi.

Pada 1979 Goa Maria Trirtis diresmikan oleh Romo Lamers, SJ dengan memasang Patung Bunda Maria. Bertitik tolak dari pengamatan, penjajagan lokasi yang ada, muncul gagasan untuk membuat karya seni yang bersumber dari situasi kondisi dan faktor fungsional Goa Maria Tritis. Berbagai elemen dimunculkan dari kedalaman memori pribadi seniman mengenai laku religi yang pernah dialami selama hidup dan selama berkreasi dalam bidang seni. Ekspresi yang muncul pun pada akhirnya sesuai dengan kemampuan seniman. Kehadiran multi ekspresi yaitu tari, teater, lagu, nyanyian, pembacaan narasi merupakan wujud dari ekspresi dan intuisi seniman.

Perwujudan seni sebagai media untuk melampiaskan emosi dan ekspresi diri merupakan pengalaman estetika, tidak hanya bagi pelaku yang menikmatinya, namun juga bagi penonton (penghayat). Ekspresi pencipta seni dan pelaku dapat dinikmati atau terjadi komunikasi dengan penghayat dan peziarah melalui simbol. Manusia dalam menghayati pola pikir dan pola rasa seperti interaksi estetis dan religius di Goa Maria Tritis memakai sarana komunikasi berupa simbol, karena simbol berhubungan erat dengan pernyataan hidup manusia. Berbagai pembentukan macam simbol dijadikan wahana oleh pencipta tari untuk menyimpan dan mengekspresikan pengalaman, sehingga akan terbentuk komunikasi dari berbagai aspek kehidupan, antara manusia dengan manusia (penghayatan kemanusiaan), manusia dengan karya manusia (penghayatan estetika), manusia dengan alam (penghayatan nilai-nilai kehidupan), dan manusia dengan Tuhan (penghayatan semesta).

Karya seni ini merupakan interpretasi-interelasi subyektif (pencipta, penari dan pendukung yang lain), dari penggambaran berdasarkan kepekaan intuisi artistik dari masing-masing pelaku dibudayakan untuk aktif melakukan penjajagan dalam segala bidang, guna menemukan dan dapat masuk ke dalam aspek bentuk dan aspek isi konsep penciptaan tari. Situasi geografis Goa Maria Tritis sangat kuat menstimulasi kepenarian serta pemeranan. Aspek eksterior dan interior menawarkan keindahan dan menimbulkan imajinasi kreatif. Berdasarkan kenyataan, situasi, kondisi demikian, menimbulkan beberapa pemikiran untuk menciptakan situasi ziarah jalan salib yang bisa berkesan kepada peziarah, memberikan ruang kreatif kepada masyarakat sekitar dalam pelayanan kepada peziarah dan kelanggengan karya seni yang ada dalam perubahan situasi dan kondisi di masa mendatang.

Upaya-upaya untuk mewujudkan gagasan pembuatan karya ini dilakukan dengan berbagai bentuk pendekatan, baik untuk mencapai halhal yang bersifat bentuk maupun konsepnya. Pendekatan terhadap hal-hal yang bersifat bentuk banyak dilakukan melalui uji coba, eksperimen, latihan-latihan yang kesemuanya bersifat penjajagan. Pendekatan terhadap konsep dilakukan dengan cara observasi dan melibatkan diri dalam pengalaman langsung ikut merasakan berbagai fenomena kehidupan religius, misal mengikuti rutinitas ekaristi gereja, melakukan ziarah jalan salib di berbagai tempat. Semua itu dilakukan untuk memperkuat rasa hayat terhadap kompleksitas dari realitas kehidupan religius, 
didukung pula oleh berbagai bentuk pengamatan baik melalui media audio visual, maupun secara langsung.

Pendekatan ruang sebagai tempat penyajian dilakukan melalui pengamatan, penjajagan tempat, hingga mengenal unsur-unsur alam yang terdapat di lokasi Goa Maria Tritis, misal adanya batu-batu karang, bukit-bukit yang berundak atau terasering hingga menyerupai piramid, karakter jalan sebagai rute jalan salib yang sangat kompleks. Pendekatan desain gerak dilakukan melalui berbagai eksperimen, latihan, penjelajahan gerak yang didukung oleh stimulasi-stimulasi, audio, visual, ritual, gagasan, maupun emosi pribadi. Kedua pendekatan artistik ini dilakukan dengan cara sendiri-sendiri dan saling silang untuk mencapai keterpaduan.

Pendekatan religius diperlukan, mengingat lokasi Goa Maria Tritis merupakan tempat ziarah bagi salah satu agama. Berbagai bacaan dalam kitab suci, buku-buku renungan, buku doa, dicoba untuk ditafsir ekspresikan melalui media gerak tubuh penari. Pendekatan sosial kemasyarakatan juga diperlukan mengingat garapan ini sekaligus melibatkan penduduk yang notabene sebagian dari penonton adalah peziarah. Sehingga diharapkan peziarah akan terlibat secara emosional, visual terhadap karya ini. Secara perlahan garapan ini juga melibatkan unsur masyarakat setempat dalam rangka memprediksi ke depan, bahwa Goa Maria Tritis akan menjadi sebuah tempat ziarah yang mampu menampilkan karya seni sebagai monumen hidup.

Pendekatan evaluasi dilakukan untuk mengontrol perkembangan garap agar selalu berjalan selaras dengan tema yang hendak diungkapkan. Evaluasi dilakukan terhadap berbagai aspek garap karya yang meliputi tata ruang pentas, tata iringan, tata gerak dan tata audience. Kontrol terhadap keempat aspek tersebut diharapkan dapat mendukung terungkapnya tema karya baik dari segi estetika dan artistik maupun dari segi pesan dan makna garapan dalam mengupas kompleksitas kemanusiawian dalam kehidupan religius.

\section{Konsep Dasar Penggarapan Karya}

Pandangan koreografer terhadap perempuan digambarkan dengan sosok Bunda Maria, seorang ibu yang selalu setia menyertai putranya dalam suka maupun duka, karena penderitaan Yesus merupakan cobaan bagi Maria sebagai wanita teguh dengan kemuliaan, ketabahan, dan kekuatannya, menjadikan Maria mendapat tempat yang khusus dan sebagai teladan bagi perempuanperempuan di seputar Yesus. Fenomena tersebut ditransformasikan ke dalam karya tari yang berjudul "Bunga di Atas Karang".

Judul ini merupakan upaya penyatuan antara tari dan stage-nya. Bunga yang dimaksud adalah Bunda Maria. Maria artinya Mawar, dianggap sebagai bunga yang terindah, bunga kerajaan yang harumnya melampaui segala bunga lainnya (Yon Lesek, 2005: 12). Batu karang merupakan bentuk batu yang besar, terjal, tajam, ditemukannya di lokasi yang akan digunakan sebagai tempat pertunjukan yaitu sebuah lokasi peribadatan atau tempat ziarah yang terdiri dari batu karang yang mengelilinginya. Dalam filsafat teologi dikemukakan bahwa sebuah tempat ziarah selalu terdapat air, bunga dan batu. Goa Maria Tritis dikelilingi oleh batu karang. Batu karang merupakan jenis batu besar, tajam dan keras yang berada di dataran tinggi yang tandus kering dan hujan yang turun tak menentu. Seseorang bisa menemukan kesejukan, kedamaian dan keindahan di antara batu-batu karang itu. Oleh karena itu Goa Maria merupakan tempat yang cocok untuk ruang memohon, kontemplasi yang sejuk dan indah, dan juga sosok yang diibaratkan sebagai bunga mawar yaitu Goa Maria yang berada di ujung jalan setapak berbatu, yang merupakan rute Jalan Salib.

\section{Konsep Garap Bunga di Atas Karang}

Garap koreografi ini sangat dipengaruhi oleh proses. Garap tari berhubungan erat dengan kreativitas yang terkait dengan proses dan bentuk. Proses adalah tahap-tahap menata dengan berbagai sentuhan emosional sesuai dengan tema atau isi yang diungkapkan. Bentuk yang berarti wujud dari sesuatu, maka yang mengarah pada sesuatu yang lebih abstrak yaitu bentuk dalam pengertian paling abstrak berarti struktur, artikulasi, hasil menyeluruh dari hubungan berbagai faktor yang saling bergayutan atau lebih tepatnya cara dirakitnya keseluruhan dari aspek (Lois Ellfeldt, 1977: 20).

Karya ini merupakan sebuah upaya untuk mengungkap fenomena jalan salib. Jalan Salib 
adalah sebuah devosi bukan merupakan liturgi. Jalan salib adalah sebuah tradisi agama Katolik (sesuai kitab) dan merupakan peristiwa-peristiwa yang beruntun dari kisah kesengsaraan Yesus Kristus. Devosi merupakan sikap hati seseorang dan perwujudannya terhadap seseorang atau sesuatu yang dijunjung tinggi dan dicintai. Patung dan gambar boleh digunakan, tetapi bukan untuk disembah, melainkan dipakai sebagai sarana untuk menghormati pribadi orang kudus yang hidup di baliknya (Martasudjita, 1999: 143-152). Devosi lebih merupakan praktik pengungkapan iman umat yang bersifat spontan dan lebih bebas, bisa dibawakan secara pribadi maupun bersama. Di dalam Gereja Katolik terdapat beraneka ragam devosi, antara lain kebaktian kepada sakramen maha kudus, jalan salib, rosario, novena dan ziarah. Hal ini berbeda dengan liturgi yang merupakan ibadat umum di gereja, merupakan tata upacara agama Kristen-Katolik karena segala tindakannya sebagai tanda pewahyuan Tuhan (Martasudjita, 1999: 18).

Bukit Golgota merupakan tempat tujuan akhir perjalanan Yesus, dalam penderitaan-Nya. Bukit Golgota merupakan tempat menancapkan salib Yesus sebagai tanda kemenangan. Keberhasilan Yesus menuju puncak Golgota tidak lepas dari peran ibu-Nya yaitu Maria. Sebagai seorang ibu, Maria selalu setia menyertai anaknya dalam suka dan duka. Penderitaan Yesus merupakan cobaan Maria sebagai wanita teguh dalam pendiriannya. Kemuliaan Maria menjadi sebuah pandangan hidup perempuan yang mengidolakannya. Kesetiaan seorang ibu, ketabahan, kekuatannya menjadikan Maria mendapat tempat yang khusus di antara orang-orang peting dalam kehidupan Yesus. Terkadang peran perempuan dilupakan, walaupun perempuan berjuang, bekerja keras, disiksa, beban hamil, dan masih banyak penderitaan lahir maupun batin tetap saja bahwa itu semua demi kesuksesan kaum pria. Namun tak terelakan bahwa kaum pria pun tak menyadari hal itu.

Kayu salib tanpa corpus (tubuh atau badan), corpus di sini adalah arca atau tubuh Yesus yang dipentingkan. Terkadang hanya dengan kayu-kayu salib yang mewakili, yang disesuaikan dengan stasi yang diperlukan. Adapun empat belas peristiwa itu adalah (a) Yesus dijatuhi hukuman mati. Peristiwa ini adalah peristiwa persidangan terhadap Yesus oleh rakyat di depan Pilatus. (b) Yesus memanggul salib. Akibat desakan rakyat terhadap Pilatus, maka Yesus harus menerima hukuman mati dengan cara disalib di bukit Golgota/Kalvari, saat itu juga salib dipanggulkan kepada Yesus. (c) Yesus jatuh pertama kali. Perjalanan menuju ke bukit Golgota sangatlah berat hingga Yesus terjatuh. (d) Yesus bertemua dengan Maria ibunya. Dalam perjalanan menuju ke bukit Golgota Yesus bertemua dengan Maria ibunya. (e) Yesus ditolong Simon dari Kirene. Simon adalah seorang petani dari Kirene yang dipaksa prajurit untuk membantu mengangkat dan memikul salib Yesus. (f) Veronica mengusap wajah Yesus. Veronika adalah seorang perempuan yang memberanikan diri untuk mengusap wajah Yesus dan membersihkan dari darah dan kotoran yang ada di wajah Yesus. (g) Yesus jatuh kedua kalinya. (h) Yesus menghibur perempuan-perempuan yang menangisinya. Perempuan-perempuan yang menangis karena kasihan terhadap Yesus, dan Yesus dengan belas kasihnya menghibur perempuan-perempuan yang manangisi dan meratapinya. (i) Yesus jatuh ketiga kalinya, (j) Pakaian Yesus ditanggalkan (k) Yesus disalibkan (l) Yesus mati disalib, (m) Yesus diturunkan dari salib, (n) Yesus dimakamkan

Bentuk karya ini adalah pertunjukan tari. Bentuk dapat digambarkan sebagai organisasi dari hasil kekuatan-kekuatan dari struktur internal tari. Bentuk adalah bukan satu bendanya itu sendiri, tetapi sebagai pengganti simbol yang menunjukkan di luar sesuatunya sendiri, ia berarti menyatakan maksud tari (Sumandiyo Hadi, 2003: 126-127). Jalan Salib merupakan peristiwa perjalanan. Artinya bahwa kejadian ini mengalami perpindahan tempat dari tempat satu ke tempat yang lain. Setiap peristiwa penting ditandai dengan gambar/relief. Berpijak dari gambargambar itu maka bentuk tablo menjadi pilihan garap bentuk yang pertama. Kesan teaterial sangat terasa pada sajian tablo ini, karena peranan dialog dominan dilakukan, di samping juga acting para pendukung. Tempat pertunjukan menggunakan rute Jalan Salib di Goa Maria Tritis. Setiap peristiwa yang hadir juga sesuai dengan stasi-stasi yang digambarkan dalam setiap gambar atau relief yang ada, dan setiap perhentian berhenti di stasi yang sesuai dengan peristiwa tersebut.

Pertunjukan tablo Jalan Salib dimulai dari jalan raya depan pintu masuk areal Goa Maria, dilanjutkan di pendapa sebagai tempat persidangan 
Yesus oleh rakyat di depan Pilatus. Perarakan dilakukan menggunakan rute Jalan Salib, di sepanjang jalan penuh variasi lereng-lereng, jalan melingkar naik turun yang terjal. Perarakan diapit oleh beberapa rahib berjubah dan berkerudung cokelat yang terus menerus melantunkan Tantum ergo: Tantum ergo sacranmentum venere mur cernu... Yesus di tengah perarakan itu dihujani dengan umpatan-umpatan dan cercaan yang menyakitkan. Peristiwa penderitaan dan kesengsaraan yang diekspresikan sendiri oleh koreografer merupakan pengungkapan kedalaman batin dan sentuhan emosional yang utuh.

Bukit yang terjal dan berundak-undak sebagai penggambaran dari bukit Golgota yaitu tempat Yesus disalibkan. Digambarkan Yesus yang merangkak menuju puncak bukit di mana salib tersebut ditancapkan. Peranan perempuan yaitu Maria yang selalu setia mengikuti Yesus demi kemenangan salib, diekspresikan dengan merangkaknya Maria menuju puncak bukit tersebut. Selain itu juga terdapat peristiwa di lereng bukit itu yang merupakan penggambaran dari peristiwa-peristiwa mengenai perjuangan perempuan dalam hidup yang penuh dengan penderitaan. Peristiwa tersebut diekspresikan dengan peran perempuan yang sedang menanggung beban hamil, perempuan yang berjuang dengan bekerja keras demi hidupnya, perempuan yang disiksa oleh beban hidupnya sendiri, wanitawanita penggoda yang menghiasi kehidupan duniawi, wanita-wanita dengan penderitaan, kesakitan dan masih banyak lagi penderitaan lahir maupun batin, sehingga ternamailah bukit itu sebagai "Bukit Perempuan". Penggambaran peristiwa tersebut dihiasi dengan musik ilustratif dan suara dari gesekan biola yang menyayat menambah tumbuhnya suasana perjuangan dengan penderitaan yang berat.

Kesendirian dalam penderitaan menjadi sebuah olah gerak tunggal yang bisa disaksikan sebagai sengsara di antara kegembiraan duniawi. Pada pohon jati, sebuah bidang tanah yang tidak begitu luas, di area hutan jati yang kecil, menjadi sebuah penggambaran salib kehidupan yang kekinian, dengan ranting-ranting yang berkarakter, tampak berdiri di salah satu batang tegak pokok pohon jati hampir separuh tinggi pohon.

Seorang penari bergerak lembut, ringan, lamban, rambut tergerai dengan kain putihnya yang melambai tertera angin. Gerakannya seperti menahan sakit yang amat sangat dan menahan derita yang dalam, dengan penuh kekuatan setelah tubuhnya berguling-gulingan di lereng ilalang kering. Dalam kesendirian, Pengkarya menarik Kristus yang bangkit setelah tersalib. Situasi yang sunyi, sepi dengan didukung adanya lagu-lagu yang dinyanyikan oleh sekelompok koor menambah suasana haru yang menggetarkan batin.

Permenungan mengenai kisah sengsara Yesus Kristus, ketabahan Maria, kemenangan salib diekspresikan dalam bentuk susunan gerak tari, pembacaan narasi dan lagu. Gerak tari yang disusun berdasarkan proses pencarian panjang melalui tahap pengamatan, penjajagan, uji coba terhadap salib dengan berbagai bentuk gerak melalui improvisasi dari penata tari maupun para pendukungnya.

Gerak tari yang hadir dalam koreografi ini merupakan pemaknaan dari salib yang ada dalam tubuh koreografer. Menurut koreografer salib tersebut adalah beban hidup. Sebesar apakah salib yang dipanggul, hanya yang melakukan yang dapat mengekspresikan, misalnya salib hidup sang koreografer yang sangat besar, menjadi penggambaran beban yang tampak berat. Peristiwa ini digambarkan oleh empat penari putra dan satu orang penari putri.

Penari putra diberi arahan dan gambaran tentang salib, dan cara untuk mengolah salib itu dalam gerak tari. Gerak tari yang muncul adalah gerak yang lambat namun penuh kekuatan yang kadang kala dilakukan secara bersama. Penari putri diberi kebebasan untuk "mengeplorasi" tempat atau ruang sebagai area pentas dan sekuntum bunga mawar yang dibawanya. Pembacaan narasi menjadi salah satu bagian dalam permenungan, dan adanya lagu-lagu serta musik Gregorian yang mengisi permenungan ini.

Permenungan dilakukan di dalam Goa Maria yang merupakan tempatziarah, merupakan tempat yang masih alami dengan stalagtit dan stalagnit dan adanya patung Bunda Maria serta patung Yesus yang disalib di antara batu karang yang menghiasi bagian dalam goa. Sebuah koreografi dengan dibantu oleh tatanan pencahayaan yang sederhana dengan harapan kesan alami goa itu tetap terjaga. 
Bunga di Atas Karang adalah bentuk pertunjukan yang melibatkan seni teater, seni tari, dan seni musik. Struktur dramatik penggarapan karya Bunga di Atas Karang diawali dari persidangan Yesus oleh Pilatus dan rakyat, dilanjutkan penyiksaan Yesus sampai dengan Simon yang membantu Yesus dalam memanggul kayu salib. Saat Yesus berguling di lading ilalang kering penuh siksaan, suasana dramatic mulai menanjak. Yesus kemudian berguling-guling di batu cadas dan merangkak menuju tempat penyaliban di bukit. Konsep gerak-gerak realis muncul mengawali penggarapan ini hingga dramatika pertunjukan tersebut mulai menanjak.

Dalam keheningan, dramatik mulai menurun yaitu dimulai dari penggambaran Yesus yang bangkit, diekspresikan di area hutan jati yang sepi dengan mengalun musik serta lagu rohani hingga menuju goa. Penurunan dramatisasi ini tampak terlihat dengan adanya gerak-gerak simbolik yang tersusun, gerak tari tersebut diekspresikan di area goa.

\section{Proses Koreografi}

Proses awal karya ini berangkat dari kegiatan mengikuti dan menggarap bentuk tablo di gereja St. Antonius Kotabaru. Pementasannya dilakukan di dalam gereja. Kemudian dicobakan dipentaskan dengan adegan peristiwa pertama di luar gereja, lalu masuk ke dalam gereja. Pementasan dilakukan di dalam gereja yang berkutat di seputar altar, tanpa adanya dekorasi, tidak ada penataan cahaya yang mendukung pertunjukan. Pengkarya mencoba membuat pementasan dengan adegan pertama, yaitu peristiwa persidangan dimulai dari sisi luar gereja, lalu masuk ke dalam gereja. Semua eksplorasi ini dikembangkannya untuk menciptakan karya berikutnya, namun Sardono W. Kusumo mengusulkan agar pengkarya mencari dan memilih lokasi lain yang lebih tepat serta menarik.

Berkaitan dengan pemilihan tempat yang tepat untuk peristiwa jalan salib, Pengkarya melakukan pencarian lokasi. Goa Maria Sendang Sono (Kulon Progo DIY), Goa Maria Sendang Jatiningsih (Sleman DIY), Goa Maria Kerep (Ambarawa, Jawa Tengah), Candi Hati Kudus Yesus Ganjuran (Bantul) serta Studio Alam Puskat, Sinduadi (Sleman) menjadi alternatif pilihan lokasi.
Namun Goa Maria Tritis yang dianggap paling tepat sebagai tempat pertunjukan, karena lokasi rute jalan salib bervariasi karakternya. Tebing tinggi berbatu padas maupun karang, jurang terjal dan curam, berbagai pepohonan yang menghijau maupun kering, nampak menghidupkan suasana dan artistik. Sementara Goa Maria Sendang Sono nampak terkesan sebagai tempat wisata, karena ramai pengunjung, dan kurang tenang sebagai tempat ibadah. Goa Maria Jatiningsih, sebenarnya menarik juga. Tempat ini terletak di pinggir sungai Progo, dengan pohon-pohon jati yang rindang, namun rute jalan salib melintasi tengah perkampungan yang padat rumah penduduk. Goa Maria Kerep terasa kurang pas juga, karena rute jalan salibnya sangat pendek dan tak berkarakter. Candi Hati Kudus Yesus Ganjuran mempunyai keunikan yaitu ujung akhir dari rute jalan salib tidak ditemui goa Maria separti yang biasa terdapat pada tempat yang lain. Tempat ini difokuskan pada candi Hati Kudus Yesus. Keunikan lainnya terdapat pada relief yang menggambarkan peristiwa jalan salib namun dengan nuansa Hindu-Jawa yang nampak pada kostum pada relief tersebut.

Memang beberapa elemen terwujud dalam karya seni pengkarya, tidak hanya tari sebagaimana disiplin ilmu yang pengkarya tekunni saat ini. Karya seni ini pun tumbuh dan berkembang dalam sebuah ruang dalam keyakinan dan kepercayaan kepada Tuhan (religiusitas).

Proses awal yang menjadi dasar karya ini adalah pementasan tablo Kisah Sengsara Yesus di Goa Maria Tritis. Pementasan didukung oleh pemain-pemain dari komunitas teater gereja st. Antonius Kota Baru Yogyakarta. Pementasan dilaksanakan ada malam hari, kondisi gelap pada rute jalan salib mengharuskan dihadirkannya penerangan yang memadai. Mengingat kondisi saat itu hujan menjadikan jalan itu licin dan jurang yang membahayakan. Obor yang terbuat dari bambu menjadi pilihan sebagai alat penerangan malam itu. Pemilihan kostum yaitu menggunakan pakaian ala prajurit Romawi, jubah-jubah besar untuk peran tokoh tertentu dan juga untuk peran rakyat. Evaluasi dilakukan sebagai pijakan karya selanjutnya. Waktu pementasan malam hari, pilihan kostum, jumlah pemain menjadi bahan pertimbangan yang cukup berarti. 
Memasuki tahap awal proses Bunga di Atas Karang, pengkarya mulai mencari dan memilih pendukung karya tersebut. Pemilihan pendukung pun juga dilakukan sendiri oleh pengkarya, melalui bentuk latihan bersama baik dalam olah gerak, olah suara, maupun dalam kepekaan rasa. Walaupun garapan ini berkaitan dengan tradisi sebuah agama, namun toh pendukung karya ini ada yang beragama lain. Para penari diberi kebebasan bergerak menurut kata hati untuk mengungkapkan salib (dalam hal ini ditekankan lebih merupakan ungkapan penderitaan batin yang mendalam). Bentuk teateral memang muncul, itupun tidak lepas dari proses bersama antara koreografer dengan para pemain teater. Perdebatan, saling tukar pengalaman, saling tukar cerita menjadi salah satu proses yang dilalui. Pengenalan dan peninjauan lokasi pementasan dilakukan secara bersama. Pengenalan medan pentas menjadi sangat penting bagi para pendukung karya ini. Penempatan alat musikpun disesuaikan dengan lokasi yang ada. Pemilihan ruang di dalam goa sangat menentukan kualitas akustik dalam menimbulkan getaran suara yang ditimbulkan beberapa alat musik dan bunyibunyian. Kesederhanaan menjadi salah satu hasil dari proses ini. Kesederhanaan kehidupan masyarakat sekitar Goa Maria Tritis menjadi inspirasi kreatif bagi koreografer. Proses pemilihan busana disesuaikan dengan busana kesehariaan masyarakat setempat. Agar di masa mendatang masyarakat setempat pun bisa mementaskan karya ini dengan sederhana apa adanya.

\section{Penutup}

Bunga di Atas Karang dipentaskan di Goa Maria Tritis, Dusun Bulu, Desa Giring, Kecamatan Paliyan, Wonosari, Gunung Kidul, DIY, yang merupakan tempat ziarah bagi umat Katolik. Pertunjukan dengan tema perempuan di balik kemenangan Yesus merupakan salah satu bentuk pertunjukan yang terdiri dari dua bagian, pertama pertunjukan berupa tablo. Tablo dalam bahasa Inggris "tableau" yang berarti cerita pendek.

Bagian pertama adalah tablo yang mengisahkan tentang cerita Jalan Salib Kesengsaraan Yesus
Kristus, yaitu perjalanan Yesus menuju ke bukit Golgota, tempat Yesus disalibkan dangan visualisasi tokoh-tokoh yang berperan dalam cerita tersebut yang disajikan secara teateral. Tablo ini dipentaskan di area luar, yaitu dipentaskan dengan menggunakan rute Jalan Salib. Bagian kedua yaitu sebuah bentuk koreografi yang mengisahkan kesengsaraan Yesus Kristus dan ketabahan Maria, pertunjukan ini disajikan dalam bentuk tari dengan diiringi musik dan lagu serta adanya pembacaan narasi. Pertunjukan tersebut dipentaskan di dalam goa yang merupakan tempat ziarah bagi umat Katolik.

Perpindahan bagian ke satu menuju ke bagian kedua diselingi dengan rehat selama 30 menit. Audience diajak untuk menyantap makanan khas Gunung Kidul seperti tiwul, gaplek dan sebagainya. Setelah bagian kedua usai, dilanjutkan dengan misa/ekaristi di dalam goa yang dipimpin oleh Romo Slamet Pr. sewu obor (seribu obor) adalah satu bagian akhir yang cukup menarik juga. Peristiwa ini merupakan perjalanan pulang para audience, umat dari goa menuju tempat parkir. Para penonton yang berjumlah cukup banyak berjalan sembari membawa alat penerangan jalan yaitu obor. Obor yang telah disediakan oleh tim produksi terbuat dari bambu. Para penonton berjalan beriringan pada jalan setapak sehingga nampak nyala obor yang berderet memanjang.

\section{Kepustakaan}

Ellfeldt, Lois, 1997. Pedoman Dasar Penata Tari, terjemahan Sal Murgiyanto dari A Primer For Choreographers. Jakarta: Lembaga Pendidikan Kesenian Jakarta.

Hadi, Y. Sumandiyo, 2003. Mencipta Lewat Tari ,Yogyakarta: Manthili.

Lesek, Yon, 2005. Rahasia Gelar-gelar Maria, Jakarta: Fidei Press.

Martasudjita E. Pr., 1999. Pengantar, Liturgi, Makna, Sejarah dan Teologi Liturgi, Pustaka Teologi, Yogyakarta: Kanisius.

Supadma, 2004. "Inovasi dan Apresiasi Tari" dalam Resital Jurnal Ilmiah Seni Pertunjukan, Edisi V/01. Juni 2004.

Sutrisno, Mudji, 2003. "Seni Tradisi dan Hak Cipta" dalam Mencermati Seni Pertunjukan I Prespektif Kebudayaan, Ritual, Hukum, Surakarta: STSI Surakarta Pers. 